\title{
PTI-1: novel way to oncogenicity
}

\author{
A. A. Vislovukh ${ }^{1}$, V. F. Shalak ${ }^{1}$, O. V. Savytskyi ${ }^{1}$, N. I. Kovalenko ${ }^{1}$, \\ N. L. Gralievska' ${ }^{1,2}$, B. S. Negrutskii ${ }^{1}$, A. V. El'skaya ${ }^{1}$ \\ ${ }^{1}$ State Key Laboratory of Molecular and Cellular Biology \\ Institute of Molecular Biology and Genetics, NAS of Ukraine \\ 150,Akademika Zabolotnoho Str., Kyiv, Ukraine, 03680 \\ ${ }^{2}$ Educational and Scientific Center «Institute of Biology», National Taras Shevchenko University of Kyiv \\ 64/13, Volodymyrska Str., Kyiv, Ukraine, 01601 \\ a.a.vislovukh@imbg.org.ua
}

\begin{abstract}
Aim. The prostate tumor-inducing oncogene (PTI-1), presumably encoding a truncated form of eukaryotic translation elongation factor $1 A 1$ (eEF1A1), was discovered as a gene overexpressed in prostate tumor samples and absent in normal tissues. The mechanism of PTI-1 oncogenicity remains obscure. Methods. Several bioinformatics methods were applied to analyze the PTI-1 mRNA structure, translation efficiency and coding potential. Results. In silico analysis of 5'UTR of its mRNA suggest that PTI-1 mRNA most probably belongs to the class of templates with low translation efficiency. Additionally, novel open reading frame (ORF) starting with alternative initiation site situated upstream of the main ORF start codon was found. Finally, the peptide that does not resemble eEF1A1 but is partially homologous to relaxin can be synthesized. Conclusions. We suggest that the alternative upstream start codon may initiate synthesis of a peptide (uPTI-1) homologous to relaxin, the hormone shown to promote the prostate cancer progression. UPTI-1 protein may interact with the respective relaxin-specific receptors, suggesting that the tumorigenic outcome of PTI-1 is possibly realized via the relaxin-dependent pathway.
\end{abstract}

Keywords: prostate cancer, PTI-1, eEF1A1, non-coding $R N A$, relaxin, ORF, uAUG.

Introduction. Prostate cancer remains one of the most prevailing reasons of male death in the world. The molecular events mediating the prostate cancer development and progression are still in the focus of laboratory studies. There is also no reliable diagnostic tool for the prostate cancer detection at early stages. One of the most intriguing questions discussed during last 20 years is a role of the putative oncogene PTI-1 in the onset of prostate tumorogenesis.

The prostate tumor inducing gene (PTI-1) was initially identified by differential RNA display analysis of cDNA derived from the human prostatic carcinoma versus normal prostate [1]. Later, the transcript of this gene was found in the prostatic carcinoma surgical samples, prostatic carcinoma cell lines (LNCaP, DU145), small-cell lung carcinoma (NCI-H69), breast carcino- ma (T47D), colon carcinoma (SW-480), tumor cell lines of hematopoietic origin, surgical specimens of pancreatic cancer and blood of patients with prostate cancer, but not in the normal and hypertrophic prostate tissues [1-4]. Initially, the PTI-1 cDNA was reported to consist of a $630 \mathrm{bp}$ long $5^{\prime}$ untranslated region (UTR) similar to 23S ribosomal RNA of Mycoplasma hyopneumoniae, and a coding region $98.4 \%$ homologous to the truncated and mutated form of translation elongation factor 1A1 (eEF1A1) mRNA [5, 6]. However, later it was demonstrated that the PTI-1 transcript encodes the truncated but not mutated form of eEF1A1[6]. In the same work it was shown that the PTI-1 5'UTR (up to $400 \mathrm{nt}$ ) can vary depending on the origin of genomic DNA. Scaggiante's group has detected a close correllation between the PTI-1 mRNA content and Mycoplas$m a$ infection [7]. They have observed the PTI-1 transcript only in cell lines and samples of prostate tumors 
infected with Mycoplasma. These data show that the PTI-1 mRNA can be a product of trans-splicing or the result of horizontal gene transfer due to chronic Mycoplasma infection. Moreover, it should be noted that infection with Mycoplasma can enhance tumor invasiveness [8].

Since the amino acid sequence of the PTI-1 protein has to be identical to eEF1A1 except for the lack of 67 amino acids from $\mathrm{N}$-terminus, the mechanism of its oncogenic action has been initially suggested to rely on its interference with the eEF1A1 canonical and/or non-canonical functions [6]. However, the PTI-1 protein itself has not been detected so far either in tumor tissues or cell line extracts, including LNCaP, the cell line where the presence of the PTI-1 transcript was originally detected [6]. This can be partially explained by a poor Kozak context of the PTI-1 mRNA initiator codon [6] and/ or presence of putative structural elements in its 5'UTR. Thus, the oncogenicity of PTI- 1 could be related to the PTI-1 transcript itself [6].

We looked for structural elements in the 5'UTR of PTI-1 mRNA that may potentially influence its translation. First, using a bioinformatics approach we found several structural elements in $5^{\prime}$ UTR that might negatively influence the PTI-1 mRNA translation. Second, we found that upstream open reading frame (uORF) in the 5 'UTR of the PTI-1 transcript was in more favorable context for translation initiation than the main open reading frame (ORF). The homology analysis and tertiary structure modeling showed that a peptide coding by this $\mathrm{UORF}$ resembles the active center of relaxin, the peptide hormone involved in the prostate cancer progression [9].

Materials and methods. Structural modeling. The uPTI-1 structure was modeled on the basis of the structures from Protein Data Bank (PDB) using Modeller 9.8 software [10]. The solution structure of omega-conotoxin GVIA (PDB code: 1OMC_A [11], residues SER6-CYS8), jingzhaotoxin-VII (PDB code: 1ZJQ_A, residues TYR20-LYS27), human relaxin (PDB code: 6RLX_B [12], residues ILE4-GLY20), ferredoxin chloroplastic transit peptide (PDB code: 1FCT_A [13], residues ARG23-MET28) were used as templates for S4C6, Y9-K17, I18-G33, R36-M42 regions of uPTI-1, respectively. Missed residues: M1-A3, T7-D8, Q11-T12, N14, I16, S22, N24-V25, S27-L28, S30-P31, N34-L35 and T41 were added using loops reconstruction option in Modeller 9.8. Homology modeling with multiple templates protocol was used, 5000 structures were generated.

The 5 best structures were selected using the Modeller Objective Function (MOLPDF), the Discrete Optimized Protein Energy (DOPE) score and the normalized DOPE score [14]. The selected structures were verified using the MolProbity web-server [15] to ensure the absence of sterical clashes, unusual rotamers and bonds, etc.

The protein modeling was performed using the infrastructure of the MolDynGrid [16] virtual laboratory (http://moldyngrid.org), based on Nordugrid ARC Middleware in the Ukrainian National Grid infrastructure (http://grid.nas.gov.ua). VMD [17] was used for radius gyration analysis, molecular graphics images were produced using the UCSF Chimera package for molecule visualization [18].

Results and discussion. The PTI-1 mRNA may be of low translation efficiency. Despite the detection of the PTI-1 transcript in different cells and tissues, there are no reports so far about the presence of a protein product of this gene in the same samples. The only result published up to date was the overexpression of $c-m y c-$ tagged PTI-1 in HeLa cells [5]. A distinct band of the $c$-myc-tagged PTI-1 protein was detected in cell extract by anti-c-myc antibody. This result was further confirmed by specific anti-eEF1A antibody which detected overexpressed $c$-myc-tagged PTI as a discrete band migrating slightly faster than the eEF1A protein [6]. It worth noting, that the amount of recombinant PTI was low comparing with endogenous eEF1A. This is also in agreement with the result obtained for the PTI-1 mRNA translation in a cell-free system [5]. It is known that a start codon of the PTI-1 ORF is situated in a poor Kozak context that may result in inefficient translation initiation and consequently small content of the protein in cell. However even placing PTI-1 ORF in a proper Kozak context resulted in weaker translation when compared to the eEF1A protein pool [6].

The efficiency of mRNA translation depends not only on the context of start codon, but also on the sequence and structure of 5'UTR [19, 20]. Thus, we checked out the presence of additional elements in the PTI-1 5 'UTR of mRNA that may potentially inhibit its translation, namely, long structured 5'UTR [21], presence of 


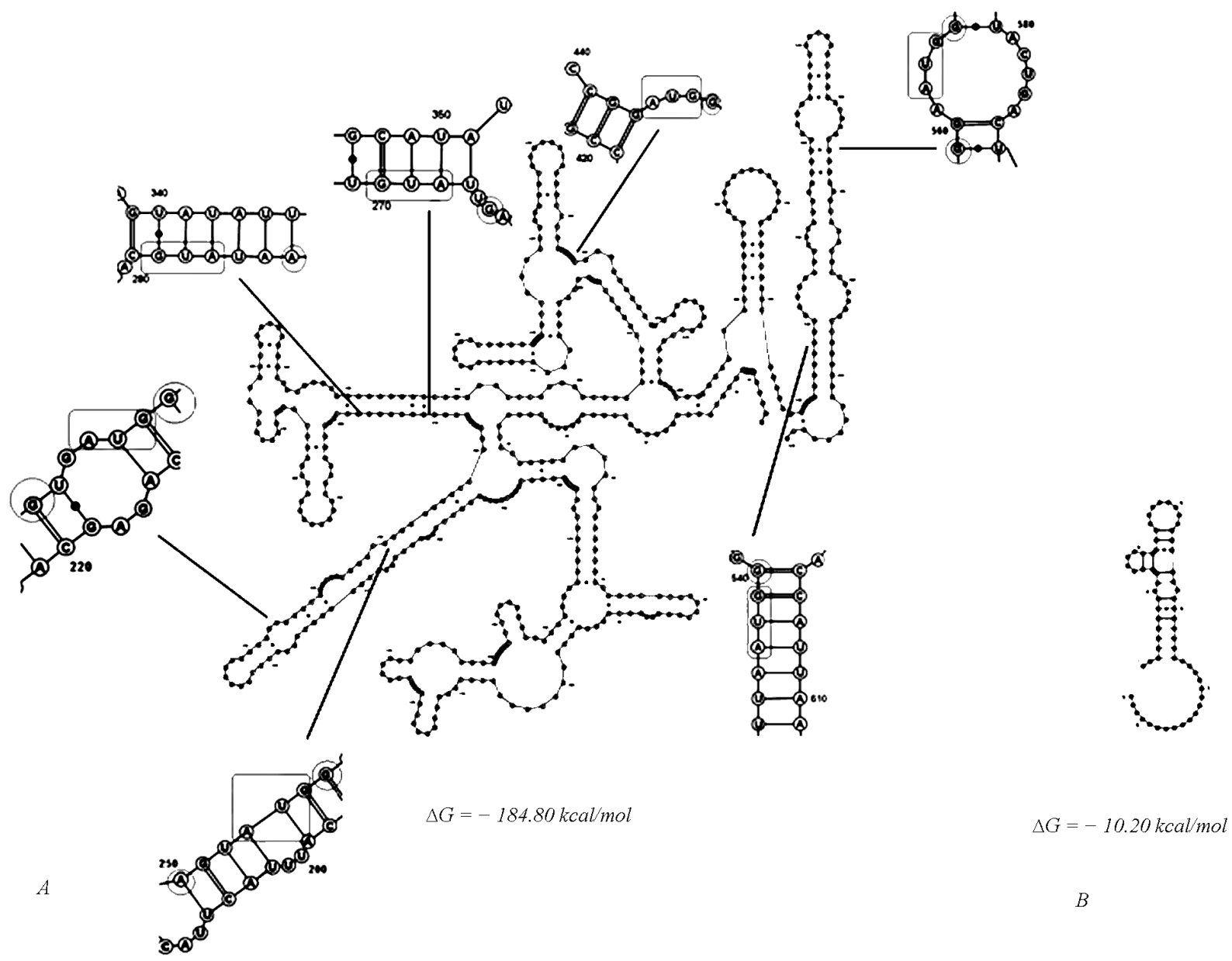

Fig. 1. $A$ - secondary structure of the PTI-1 mRNA 5'UTR (upstream AUG codons marked by rectangles, elements of Kozak context marked by circles); $B$ - secondary structure of the eEF1A1 mRNA 5'UTR

upstream start codons [22], and preferable uORFs [23]. The weakly translated transcripts, such as mRNAs of hormones and growth factors, often have a long 5'UTR with numerous secondary structures. The PTI-1 5'UTR is extremely structured (Fig. 1, $A$ ) in contrast to the 5'UTR of mRNA coding for its homologue, eEF1A1 (Fig. 1, B). Using RNALfold [24] we analyzed the 5'UTR of PTI-1 mRNA. The RNA stem-loop structures with $\mathrm{G}$ less than $-30 \mathrm{kcal} / \mathrm{mol}$ in proximal to cap region and lower than $-50 \mathrm{kcal} / \mathrm{mol}$ in distal regions, which can completely block the initiation of translation [25], have not been found.

However, we observed several secondary structures that can potentially inhibit the initiation of the PTI-1 mRNA translation (Fig. 1, $A$ ).

Upstream AUG was also shown to inhibit strongly the translation of main ORF, especially if it is situated in favorable context. In the 5'UTR of PTI-1 mRNA se- ven upstream AUG (uAUG) codons were found (Fig. $1, A)$, three among them are in a strong Kozak context. Thus, their competition with AUG codon of the main PTI-1 ORF is highly possible. Preferable translation of one of the uORFs may also have a negative effect on translation of the main PTI-1 ORF. Indeed, the PTI-1 5'UTR contains 3 uORFs, two of them in a strong Kozak context (Suppl., Fig. 1), in contrast to the main ORF homologous with the eEF1A1.

Taking into account the data obtained, we have concluded that the PTI-1 mRNA belongs most probably to the class of templates with low efficiency of translation due to the particular features of thePTI-1 5' UTR .

Searching for biologically relevant non-coding $R N A s$ in the 5'UTR of PTI-1 mRNA. Since the oncogenic mechanism that may be triggered by the PTI- 1 protein is doubtful, we looked more closely at the PTI-1 mRNA as a possible source of other oncogenic factors. Earlier, 


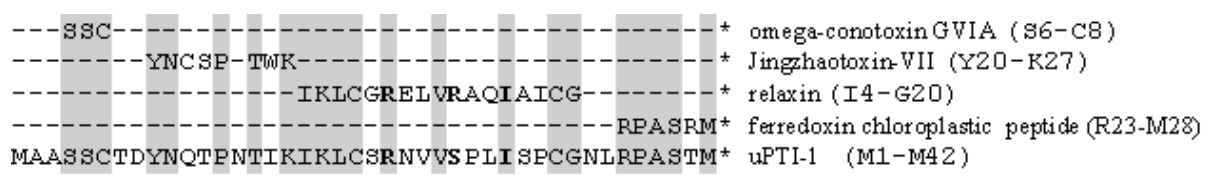

Fig. 2. Result of the uPTI-1 homology search using HHPred. Numbers of residues homologous to uPTI-1 are noted in brackets. The amino acid residues essential for the function of relaxin are marked in bold an attempt to elucidate which part of the PTI-1 mRNA is related to the tumor induction has been undertaken [26].

In the nude mice model, no tumors were developed when animals were injected with the cells possessing the 1-500 nt fragment of the 5'UTR (without 125 nt close to ORF) or the PTI-1 ORF itself that is homologous to the eEF1A1 ORF. A negative effect was also observed when the introduced cells carried the combination of abovementioned PTI-1 regions. The tumors were developed only in the case of injecting the cells harboring the full PTI-1 cDNA, thus, possessing the 501$625 \mathrm{nt}$ region in the 5'UTR [26]. Based on aforementioned data one may conclude that just 501-625 nt region is responsible for the oncogenic properties of PTI1. What could be a possible mechanism of the oncogenicity of this PTI-1 mRNA fragment?

Firstly, the 501-625 bp PTI-1 mRNA region can be a binding site for some trans-factors controlling mRNA turnover and translation. In this case, the produced PTI$1 \mathrm{mRNA}$ could sequester these factors, thus, blocking their cellular function. As a consequence, translation of some proto-oncogenes mRNAs could be increased [27]. Secondly, this region can act as non-coding RNA, or catalytic RNA, and target mRNAs of some oncosupressors like in [28]. Besides, the PTI-1 mRNA may contain alternative $\mathrm{uORF}$ s coding for some oncoproteins.

To address first two issues we performed in silico analysis of the 501-625 nt fragment of the PTI-1 mRNA. However, search for the regulatory motifs and structures in the databases of known regulatory non-coding RNAs [29-31] gave negative result (data not shown).

A peptide encoded by $\mathrm{OORF}$ present in the PTI-1 $m R N A$ has structural similarity with the peptide hormone relaxin. As mentioned above, the 5'UTR of PTI-1 transcript has several $\mathrm{uAUG}$ codons in a better Kozak context than AUG for the putative PTI-1 protein. Using ORF finder [32], we checked whether these uAUG(s) can be used as a start for a respective uORFs. The uAUG codon in position 562-564 was situated in the most favorable Kozak context. The length of corresponding
uORF was $129 \mathrm{nt}$, thus, a putative translated peptide (uPTI-1) should contain 42 amino acids.

The analysis of the uPTI-1 amino acid sequence using TermiNator $[33,34]$ server confirmed that such polypeptide may possess longer half-life and may be more efficiently synthesized in comparison with the PTI-1 protein (Suppl., Table 1). We performed the homology search in order to figure out a possible function of this peptide. Using HHpred [35] we found that a part of the uPTI-1 peptide sequence shares $53 \%$ homology with the B-chain of relaxin (Fig. 2), a peptide hormone that is synthesized in prostate and was shown to promote prostate cancer progression [36, 37]. Importantly, this high homology sequence corresponds to the active center of relaxin.

It has been shown that the location of conserved RXXXRXX(I/V) motif on one side of the alpha-helix of B-chain is an essential requirement for the interaction of relaxin with its receptor [38]. For this reason we performed the tertiary structure modeling of the uPTI-1 peptide to test whether it may resemble the relaxin active center.

Using Modeller 9.8 we generated 5000 structures. The structure number 1723 of the UPTI-1 peptide with lowest DOPE and Modeller Objective Function (MOF) scores has the best quality values (Suppl., Fig. 2). The radius of gyration (Rgyr) of modeled uPTI_1723 structure was $12.46 \mathrm{C}$ and for relaxin «6RLX» was $7.78 \mathrm{C}$. Difference in Rgyr between uPTI_1723 and 6RLX may be explained by the various coordinate topology and amino acid sequences of $\mathrm{N}$-and $\mathrm{C}$-terminus. However, all selected structures testify for a globular structure of the peptide.

As shown in Fig. 3, the model of the UPTI-1 peptide structure resembles the relaxin B-chain structure. Notably, the H2 $\alpha$-helix of the UPTI-1 peptide, a secondary structure element required for the receptor binding, is quite similar to the relaxin active center [38]. The only difference is the presence of arginine residue (R13) in relaxin instead of serine residue (S27) in UPTI-1. It should be mentioned that for effective receptor binding 

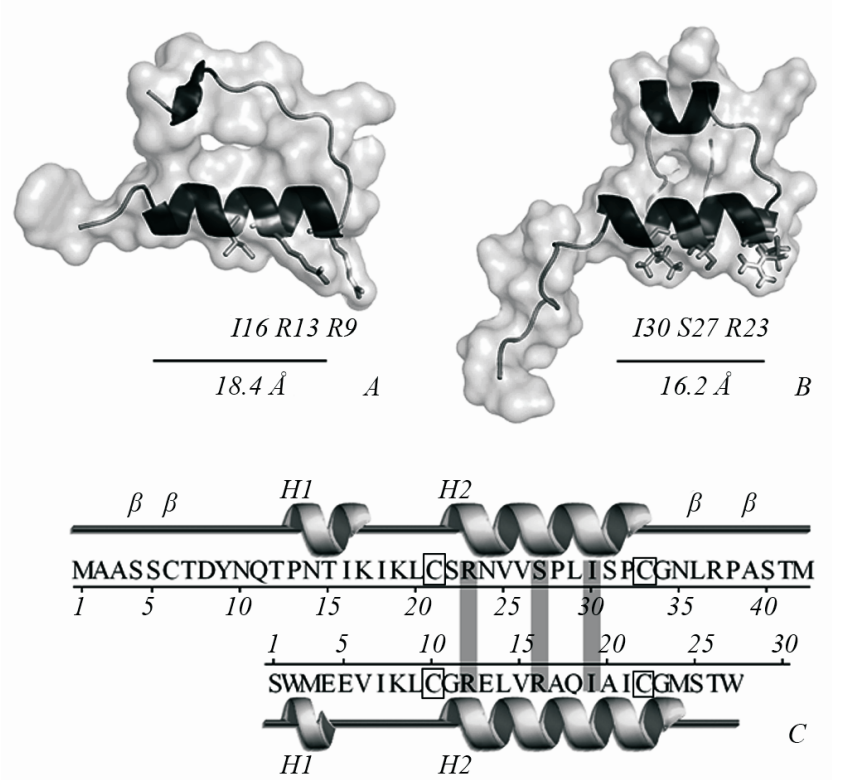

Fig. 3. $A$ - tertiary structure of relaxin B-chain; $B$-predicted tertiary structure of uPTI-1 (exposed amino acids, essential for the relaxin functioning, and sizes of alpha helixes are shown); $C$ - secondary structure analysis of uPTI-1 (upper structure) and of human relaxin 6RLX_B (lower structure) performed by PDBsum web-server [47]. RXXXRXX $(\mathrm{I} / \mathrm{V})$ motif similarity is shown using gray lines, cysteins that are responsible for interaction with A-chain marked with squares

relaxin should contain both A and B chains. We believe uPTI-1 preserves the possibility to interact with A-chain of relaxin since it contains all cysteins responsible for such interaction [39] (Fig. 3, C). However, it is still questionable whether the uPTI-1 peptide requires Achain for relaxin receptor binding or it is able to activate relaxin receptor by its own mechanism.

As relaxin is a peptide hormone it is secreted to the extracellular environment. To verify if uPTI- 1 can potentially act as relaxin, we analyzed amino acid sequence of UPTI-1 by several programs that can predict localization of a protein [40-43], and all of them predicted its extracellular localization (Suppl., Table 2).

In female, relaxin is produced by the corpus luteum of the ovary, breast, placenta, chorion, and decidua during pregnancy. In male, it is synthesized in prostate and is present in semen [44]. Importantly, relaxin was shown to promote the prostate cancer progression [36, 37]. Moreover, the increased invasiveness and migration of the breast, endometrial, and thyroid adenocarcinoma cells were induced by relaxin in vitro. These effects were accompanied by the up-regulation of matrix metalloproteinase activity and vascular endothelial growth factor expression, directly related to the cancer progression $[9,45,46]$. The relaxin-like peptide family belongs to the insulin superfamily and consists of 7 peptides of high conformational but low sequence similarity [47].

We believe that despite one amino acid substitution the UPTI-1 protein should be able to interact with the relaxin receptor since its overall architecture remains quite similar to relaxin and two other key amino acid residues (R23 and I30) of the active center are conserved (Fig. 3).

Conclusions. A novel mode of the PTI-1 oncogene action is hypothesized, which has not yet been considered but seems to be rather promising. The PTI-1 mRNA may be regarded as a template for the relaxin-like peptide synthesis. The uPTI-1 peptide may interact with the respective relaxin-specific receptors, thus, promoting the prostate cancer development via a relaxin-dependent pathway.

Acknowledgements. Authors would like to thank Anton Iershov and Semen Yesylevskyy for consultations on python script methodology of modeling in silico and some technical support. We thank Charlotte R. Knudsen for stimulating discussions.

А. А. Вісловух, В. Ф. Шалак, О. В. Савицький, Н. І. Коваленко, Н. Л. Гралєвська, Б. С. Негруиький, А. В. Єльська

PTI-1: новий шлях участі в онкогенезі

Резюме

Мета. Онкоген, який індукує рак простати (РTI-1), може кодувати вкорочену форму фактора елонгаиії еEF1A1. PTI-1 відкрито як ген, щио надекспресується у зразках раку простати і не екпресується у нормальній тканині. Механізм онкогенної дії PTI-1 на сьогодні залишається нез'ясованим. Методи. Біоінформатичні методи застосовано для аналізу структури, ефективності трансляції $і$ кодуючого потениіалу мРНК РТI-1. Результати. Аналізом іп silico 5'UTR мPHK PTI-1 виявлено, щуо зазначений транскрипт належить до класу мРНК з низькою ефективністю трансляиії. Додатково визначено нову відкриту рамку зчитування (ORF), яка починається з альтернативного старт-кодону і передує основній ORF. Пептид, що не має гомологї̈ з еEF1A1, але частково гомологічний релаксину, потенційно може синтезуватися з иієї альтернативної ORF. Висновки. Ми припустили, що з альтернативного старт-кодону починається синтез пептиду (иРTI-1), гомологічного релаксину, - гормону, що, як відомо, бере участь в індукиії раку простати. Білок иРТI-1 може взаємодіяти з відповідним рецептором клітини, специфічним для релаксину, спричиняючи ї̈ трансформацію. Таким чином, онкогенна дія гена PTI-1 може реалізуватися релаксин-опосередкованим шиляхом.

Ключові слова: рак простати, РTI-1, еЕF1A1, некодуюча РНК, релаксин, ORF, uAUG. 
А. А. Висловух, В. Ф. Шалак, А. В. Савиџкий, Н. И. Коваленко, Н. Л. Гралевская, Б. С. Негруикий, А. В. Ельская

PTI-1: новый путь участия в онкогенезе

Резюме

Цель. Онкоген, индуцирующчий рак простаты (РТI-1), может кодировать укороченную форму фактора элонгации еЕF1A1. PTI-1 открыт как ген, сверхэкспрессирующийся в образияах рака простаты и не экспрессируюшийся в нормальной ткани. Механизм онкогенного действия PTI-1 на сегодня остается неизвестным. Методы. Биоинформатические методы применены для анализа структуры, эффективности трансляции и кодирующего потенцииала мРНК PTI-1. Результаты. С использованием анализа іn silico 5'UTR мPHК PTI-1 виявлено, что указанный транскрипт принадлежит к классу мРНК с низкой эффективностью трансляичи. Дополнительно определена новая открытая рамка считывания (ORF), начинающаяся с альтернативного старт-кодона и находящаяся перед основной ORF. Пептид, не имеющий гомологии с еEF1A1, но частично гомологичный релаксину, потенциально может синтезироваться с этой альтернативной ORF. Выводы. Mы предположили, что с альтернативного старт-кодона начинается синтез пептида (иРТI-1), гомологичного релаксину, -гормону, участвующему, как известно, в индукции рака простаты. Белок иРТI-1 может взаимодействовать с соответствуюшим реиептором клетки, специфическим для релаксина, приводя кее трансформации. Таким образом, онкогенное действие гена PTI-1 может реализоваться релаксин-опосредованным путем.

Ключевые слова: рак простаты, PTI-1, еЕF1A1, некодирующзая $P H K$, релаксин, ORF, иAUG.

\section{REFERENCES}

1. Sun Y., Lin J., Katz A. E., Fisher P. B. Human prostatic carcinoma oncogene PTI-1 is expressed in human tumor cell lines and prostate carcinoma patient blood samples // Cancer Res.-1997.57, N 1.-P. 18-23.

2. Bertram J., Palfner K., Hiddemann W., Kneba M. Overexpression of ribosomal proteins L4 and L5 and the putative alternative elongation factor PTI-1 in the doxorubicin resistant human colon cancer cell line LoVoDxR // Eur. J. Cancer.-1998.-34, N 5.-P. 731-736.

3. Beyer-Sehlmeyer G., Hiddemann W., Wormann B., Bertram J. Suppressive subtractive hybridisation reveals differential expression of serglycin, sorcin, bone marrow proteoglycan and prostatetumour-inducing gene I (PTI-1) in drug-resistant and sensitive tumour cell lines of haematopoetic origin // Eur. J. Cancer.1999.-35, N 12.-P. 1735-1742.

4. Ohnami S., Matsumoto N., Nakano M., Aoki K., Nagasaki K., Sugimura T., Terada M., Yoshida T. Identification of genes showing differential expression in antisense K-ras-transduced pancreatic cancer cells with suppressed tumorigenicity // Cancer Res.-1999.59, N 21.-P. 5565-5571.

5. Shen R., Su Z. Z., Olsson C. A., Fisher P. B. Identification of the human prostatic carcinoma oncogene PTI-1 by rapid expression cloning and differential RNA display // Proc. Natl Acad. Sci. USA.-1995.-92, N 15.-P. 6778-6782.

6. Mansilla F., Hansen L. L., Jakobsen H., Kjeldgaard N. O., Clark B. F., Knudsen C. R. Deconstructing PTI-1: PTI-1 is a truncated, but not mutated, form of translation elongatin factor $1 \mathrm{~A} 1, \mathrm{eEF}-$ 1A1 // Biochim. Biophys. Acta.-2005.-1727, N 2.-P. 116-124.
7. Scaggiante B., Bonin S., Cristiano L., Siracusano S., Stanta G., Dapas B., Giansante C., Fiotti N., Grassi G. Prostate-tumor-inducing gene-1 analysis in human prostate cancer cells and tissue in relation to Mycoplasma infection // Cancer Invest.2008.-26, N 8.-P. 800-808.

8. Ketcham C. M., Anai S., Reutzel R., Sheng S., Schuster S. M., Brenes R. B., Agbandje-McKenna M., McKenna R., Rosser C. J., Boehlein S. K. p37 induces tumor invasiveness // Mol. Cancer Ther.-2005.-4, N 7.-P. 1031-1038.

9. Binder C., Hagemann T., Husen B., Schulz M., Einspanier A. Relaxin enhances in vitro invasiveness of breast cancer cell lines by up-regulation of matrix metalloproteases // Mol. Hum. Reprod.-2002.-8, N 9.-P. 789-796.

10. Eswar N., Eramian D., Webb B., Shen M. Y., Sali A. Protein structure modeling with MODELLER // Methods Mol. Biol.-2008.426.-P. 145-159.

11. Davis J. H., Bradley E. K., Miljanich G. P., Nadasdi L., Ramachandran J., Basus V. J. Solution structure of omega-conotoxin GVIA using 2-D NMR spectroscopy and relaxation matrix analysis // Biochemistry.-1993.-32, N 29.-P. 7396-7405.

12. Eigenbrot C., Randal M., Quan C., Burnier J., O'Connell L., Rinderknecht E., Kossiakoff A. A. X-ray structure of human relaxin at $1.5 \mathrm{C}$. Comparison to insulin and implications for receptor binding determinants // J. Mol. Biol.-1991.-221, N 1.-P. 15-21.

13. TranQui D., Jesior J. C. Structure of the ferredoxin from Clostridium acidurici: model at $1.8 \mathrm{C}$ resolution // Acta Crystallogr. D Biol. Crystallogr.-1995.-51, Pt 2.-P. 155-159.

14. Shen M. Y., Sali A. Statistical potential for assessment and prediction of protein structures // Protein Sci.-2006.-15, N 11.P. 2507-2524.

15. Chen V. B., Arendall W. B., Headd J. J., Keedy D. A., Immormino R. M., Kapral G. J., Murray L. W., Richardson J. S., Richardson $D$. C. MolProbity: all-atom structure validation for macromolecular crystallography // Acta Crystallogr. D Biol. Crystallogr.-66, Pt 1.-P. 12-21.

16. Salnikov A., Sliusar I., Sudakov O., Savytskyi O., Kornelyuk A. Virtual laboratory MOLDYNGRID as a part of scientific infrastructure for biomolecular simulations // Int. J. Comput.-2010.9, N 4.-P. 295-301.

17. Humphrey $W$., Dalke A., Schulten K. VMD: visual molecular dynamics // J. Mol. Graph.-1996.-14, N 1.-P. 33-38.

18. Pettersen E. F., Goddard T. D., Huang C. C., Couch G. S., Greenblatt D. M., Meng E. C., Ferrin T. E. UCSF Chimera - a visualization system for exploratory research and analysis // J. Comput. Chem.-2004.-25, N 13.-P. 1605-1612.

19. Meijer H. A., Thomas A. A. Control of eukaryotic protein synthesis by upstream open reading frames in the 5 -untranslated region of an mRNA // Biochem. J.-2002.-367, Pt 1.-P. 1-11.

20. Pickering B. M., Willis A. E. The implications of structured 5' untranslated regions on translation and disease // Semin. Cell Dev. Biol.-2005.-16, N 1.-P. 39-47.

21. Davuluri R. V., Suzuki Y., Sugano S., Zhang M. Q. CART classification of human 5' UTR sequences // Genome Res.-2000.-10, N 11.-P. 1807-1816.

22. Geballe A. P., Morris D. R. Initiation codons within 5'-leaders of mRNAs as regulators of translation // Trends Biochem. Sci.1994.-19, N 4.-P. 159-164.

23. Morris D. R., Geballe A. P. Upstream open reading frames as regulators of mRNA translation // Mol. Cell Biol.-2000.-20, N 23.P. 8635-8642.

24. Hofacker I. L., Priwitzer B., Stadler P. F. Prediction of locally stable RNA secondary structures for genome-wide surveys // Bioinformatics.-2004.-20, N 2.-P. 186-190. 
25. Kozak M. Circumstances and mechanisms of inhibition of translation by secondary structure in eukaryotic mRNAs // Mol. Cell Biol.-1989.-9, N 11.-P. 5134-5142.

26. Su Z., Goldstein N. I., Fisher P. B. Antisense inhibition of the PTI-1 oncogene reverses cancer phenotypes // Proc. Natl Acad. Sci. USA.-1998.-95, N 4.-P. 1764-1769.

27. Ebert M. S., Sharp P. A. MicroRNA sponges: progress and possibilities // RNA.-2010.-16, N 11.-P. 2043-2050.

28. Luzi E., Marini F., Tognarini I., Carbonell Sala S., Galli G., Falchetti A., Brandi M. L. Ribozyme-mediated compensatory induction of menin-oncosuppressor function in primary fibroblasts from MEN1 patients // Cancer Gene Ther.-2010.-17, N 11.P. 814-825.

29. Grillo G., Turi A., Licciulli F., Mignone F., Liuni S., Banfi S., Gennarino V. A., Horner D. S., Pavesi G., Picardi E., Pesole G. UTRdb and UTRsite (RELEASE 2010): a collection of sequences and regulatory motifs of the untranslated regions of eukaryotic mRNAs // Nucleic Acids Res.-38 (Database issue).-D75-80.

30. Bengert P., Dandekar T. A software tool-box for analysis of regulatory RNA elements // Nucleic Acids Res.-2003.-31, N 13.P. 3441-3445.

31. Jacobs G. H., Chen A., Stevens S. G., Stockwell P. A., Black M. A., Tate W. P., Brown C. M. Transterm: a database to aid the analysis of regulatory sequences in mRNAs // Nucleic Acids Res.2009.-37 (Database issue).-D 72-76.

32. Stothard $P$. The sequence manipulation suite: JavaScript programs for analyzing and formatting protein and DNA sequences // Biotechniques.-2000.-28, N 6.-P. 1102, 1104.

33. Martinez A., Traverso J. A., Valot B., Ferro M., Espagne C., Ephritikhine G., Zivy M., Giglione C., Meinnel T. Extent of Nterminal modifications in cytosolic proteins from eukaryotes // Proteomics.-2008.-8, N 14.-P. 2809-2831.

34. Frottin F., Martinez A., Peynot P., Mitra S., Holz R. C., Giglione $C$., Meinnel $T$. The proteomics of N-terminal methionine cleavage // Mol. Cell Proteomics.-2006.-5, N 12.-P. 2336-2349.

35. Soding J. Protein homology detection by HMM-HMM comparison // Bioinformatics.-2005.-21, N 7.-P. 951-960.

36. Feng S., Agoulnik I. U., Bogatcheva N. V., Kamat A. A., KwabiAddo B., Li R., Ayala G., Ittmann M. M., Agoulnik A. I. Relaxin promotes prostate cancer progression // Clin. Cancer Res.-2007.13, N 6.-P. 1695-1702.

37. Feng S., Agoulnik I. U., Truong A., Li Z., Creighton C. J., Kaftanovskaya E. M., Pereira R., Han H. D., Lopez-Berestein G., Klonisch T., Ittmann M. M., Sood A. K., Agoulnik A. I. Suppression of relaxin receptor RXFP1 decreases prostate cancer growth and metastasis // Endocr. Relat. Cancer.-2010.-17, N 4.-P. 10211033.

38. Bullesbach E. E., Schwabe C. LGR8 signal activation by the relaxin-like factor // J. Biol. Chem.-2005.-280, N 15.-P. 1458614590.

39. Zhang S., Hughes R. A., Bathgate R. A., Shabanpoor F., Hossain M. A., Lin F., van Lierop B., Robinson A. J., Wade J. D. Role of the intra-A-chain disulfide bond of insulin-like peptide 3 in binding and activation of its receptor, RXFP2 // Peptides.-2010.31, N 9.-P. 1730-1736.

40. Chou K. C., Shen H. B. A new method for predicting the subcellular localization of eukaryotic proteins with both single and multiple sites: Euk-mPLoc 2.0 // PLoS One.-2010.-5, N 4.e9931.

41. Blum T., Briesemeister S., Kohlbacher O. MultiLoc2: integrating phylogeny and Gene Ontology terms improves subcellular protein localization prediction // BMC Bioinformatics.-2009.10.-P. 274.

42. Horton P., Park K. J., Obayashi T., Fujita N., Harada H., AdamsCollier C. J., Nakai K. WoLF PSORT: protein localization predictor // Nucleic Acids Res.-2007.-35 (Web Server issue).W585-587.

43. Chou K. C., Shen H. B. Cell-PLoc: a package of Web servers for predicting subcellular localization of proteins in various organisms // Nat. Protoc.-2008.-3, N 2.-P. 153-162.

44. Ivell R., Kotula-Balak M., Glynn D., Heng K., Anand-Ivell R. Relaxin family peptides in the male reproductive system - a critical appraisal // Mol. Hum. Reprod.-2011.-17, N 2.-P. 71-84.

45. Hombach-Klonisch S., Bialek J., Trojanowicz B., Weber E., Holzhausen H. J., Silvertown J. D., Summerlee A. J., Dralle H., Hoang-Vu C., Klonisch T. Relaxin enhances the oncogenic potential of human thyroid carcinoma cells // Am. J. Pathol.2006.-169, N 2.-P. 617-632.

46. Kamat A. A., Feng S., Agoulnik I. U., Kheradmand F., Bogatcheva N. V., Coffey D., Sood A. K., Agoulnik A. I. The role of relaxin in endometrial cancer // Cancer Biol. Ther.-2006.-5, N 1.P. 71-77.

47. Chan L. J., Hossain M. A., Samuel C. S., Separovic F., Wade J. $D$. The relaxin peptide family - structure, function and clinical applications // Protein Pept. Lett.-2011.-18, N 3.-P. 220-229.

Received 20.08.12 